\title{
A fraction derived from brewer's yeast inhibits cholesterol synthesis by rat liver preparations in vitro
}

\author{
BY E. S. HOLDSWORTH, D. V. KAUFMAN AND E. NEVILLE \\ Biochemistry Department, University of Tasmania, Hobart, Tasmania, Australia
}

(Received 21 February 1990-Accepted 3 August 1990)

\begin{abstract}
Brewer's yeast was grown on a defined medium containing tracer ${ }^{51} \mathrm{Cr}$ with or without added chromium. The two batches of yeast contained $10 \mu \mathrm{g} / \mathrm{g}$ (high-Cr) or $80 \mathrm{ng} / \mathrm{g}$ (low-Cr). Extracts were prepared and fractionated. A third batch of yeast (third batch) was grown with added $\mathrm{Cr}$, and fractionated. Rats were reared on either rat cubes (normal diet) or on a low-Cr diet (low-Cr), or on rat cubes with added cholestyramine (cholestyramine diet). Preparations of rat liver, both cell-free and intact hepatocytes, incorporated acetate-carbon into fatty acids and cholesterol. These processes were inhibited by a yeast fraction containing small, neutral, water-soluble compounds. The degree of inhibition was the same whether the liver came from normal rats or rats fed on the low-Cr diet. Similarly the inhibitory effect was found with identical amounts of extracts from low- or high-Cr yeasts. Therefore, $\mathrm{Cr}$ compounds do not appear to account for the inhibitory effects of brewer's yeast. Use of other substrates indicated that the site of inhibition of sterol synthesis was apparently between acetyl-CoA and mevalonate. One inhibitory substance was isolated from yeast and was found to be nicotinamide riboside. This may have been produced from NAD(P) during the preparation of yeast extracts, and it may be produced from dietary yeast supplements during digestion in vivo. Nicotinamide riboside may be partly responsible for the reported effects of yeast supplements on plasma lipids in humans.
\end{abstract}

Brewer's yeast: Chromium: Cholesterol biosynthesis: Rat

High serum cholesterol and low serum high-density-liprotein (HDL)-cholesterol are risk factors for coronary artery disease (CAD) (Miller et al. 1977). During investigations to study the effects of brewer's yeast on the prevention of glucose intolerance in humans, it was found that dietary supplements of brewer's yeast lowered serum cholesterol or raised serum HDL-cholesterol, or both (Offenbacher \& Pi-Sunyer, 1980; Elwood et al. 1982; Grant \& McMullen, 1982; Vinson \& Bose, 1984), although other studies have failed to demonstrate such effects (Rabinowitz et al. 1983; Hunt et al. 1985; Offenbacher et al. 1985). Brewer's yeast has been considered to be a good source of the organically-bound chromium alleged to be the substance involved (reviewed by Wallach, 1985), and animals reared on low-Cr diets have been reported to have raised serum cholesterol levels (Schroeder, 1969; Stoecker \& Oladut, 1985). Supplementation of the diet with inorganic $\mathrm{Cr}$ has been reported to lower serum cholesterol or raise HDL-cholesterol, or both, in humans (Riales \& Albrink, 1981) and animals (Schroeder, 1969; Stoecker \& Oladut, 1985) and to decrease aortic plaques in rabbits (Abraham et al. 1982), but again other studies have failed to show an effect on serum lipids (Preston et al. 1976; Rabinowitz et al. 1983; Uusitupa et al. 1983; Offenbacher et al. 1985; Potter et al. 1985; Bourn et al. 1986; Li \& Stoecker, 1986). Donaldson et al. (1985) were unable to attribute differences in plasma cholesterol entirely to differences in dietary $\mathrm{Cr}$ levels. Nevertheless serum or plasma $\mathrm{Cr}$ levels have been found to be substantially lower in patients with CAD than in patients with other types of heart disease (Newman et al. 1978; Simonoff et al. 1984; Conri et al. 1986).

In view of the importance of CAD, it seemed desirable to test brewer's yeast fractions 
for effects on cholesterol homeostasis, with the aim of identifying any active component and assessing the involvement of $\mathrm{Cr}$. The liver is the major site of cholesterol synthesis, and some inhibitors of cholesterol synthesis have been found to improve blood lipid profiles in experimental animals (for review, see Brown \& Goldstein, 1986). Therefore, inhibition of liver cholesterol synthesis is one possible way in which yeast supplements might affect cholesterol levels, although inhibition of liver cholesterol synthesis does not necessarily lower blood cholesterol levels (Brown \& Goldstein, 1986). The present paper reports on effects of brewer's yeast fractions on cholesterol synthesis by rat liver preparations in vitro. Normal rats, and also rats raised on a low-Cr diet or on a cholestyramine diet, were used in the present work; yeast fractions were derived from yeast preparations differing more than 100 -fold in $\mathrm{Cr}$ content.

EXPERIMENTAL METHODS

Growth and fractionation of brewer's yeast

Brewer's yeast was grown on a defined medium of glucose, ammonium sulphate, vitamins and minerals as described by Davies et al. (1985). Two batches of yeast, one grown with trace levels of $\mathrm{Cr}$ salt and another with $1 \mathrm{mg} \mathrm{Cr}^{3+} / 1$ were extracted with $0.5 \mathrm{M}$-ammonia and fractionated on Biogel $\mathrm{P}_{4}$, DEAE Sephadex A25 at $\mathrm{pH} 4$, and Dowex 50 in $\mathrm{H}^{+}$form as previously described (Davies et al. 1985; Holdsworth \& Neville, 1988). Fraction N1 contained water-soluble material, with molecular weight less than 1300 , which did not bind to Dowex $50 \mathrm{H}^{+}$. A third batch of yeast was grown in medium containing $1 \mathrm{mg} \mathrm{Cr} \mathrm{Cr}^{3+} / \mathrm{l}$, harvested and fractionated as shown in Fig. 1. After extraction with $0.5 \mathrm{M}$-ammonia the extract was passed through a membrane filter passing material of less than 10000 molecular weight and freeze-dried. A solution of the residue in water at $\mathrm{pH} 8.5$ was passed down a column $(50 \times 1000 \mathrm{~mm})$ of $150 \mathrm{~g} \mathrm{DEAE}$ Sephadex A25 which had been equilibrated with $0.05 \mathrm{~m}$-ammonia solution. With these conditions inhibitory material was retarded on the column. The column was washed with $250 \mathrm{ml} 0.05 \mathrm{M}$-ammonia, then with $700 \mathrm{ml}$ distilled water followed by dilute acetic acid $(0 \cdot 1 \mathrm{M})$ and finally with $1 \mathrm{M}$-acetic acid. Fractions were freeze-dried and portions tested for their ability to inhibit incorporation of $\left[1-{ }^{14} \mathrm{C}\right]$ acetate into non-saponifiable lipid. Fractions DE2, DE3 and DE4 had this activity and each was fractionated further by passing through a column of Dowex 50 . With fractions DE2 and DE3 the column of Dowex 50 was in $\mathrm{H}^{+}$form and it was subsequently found that the low $\mathrm{pH}$ encountered within the column destroyed some of the inhibitory activity. For this reason fraction DE4 was fractionated on a column of Dowex 50 in $\mathrm{NH}_{4}{ }^{+}$form at $\mathrm{pH}$ (water effluent) 4.0. In all instances the inhibitory activity was not retained by the Dowex 50, therefore material washed through these columns with water was collected and freeze-dried to give fractions NA, NB, NC, ND.

Fraction ND was further fractionated by high-performance liquid chromatography on a Pharmacia column of polyanion (S1 HR 5/5) which had been well-washed with $1 \mathrm{M}$-acetic acid and then water. A total of five $1 \mathrm{ml}$ portions were processed using a linear gradient, water to $0 \cdot 1 \mathrm{M}$-acetic acid, with a flow-rate of $1 \mathrm{ml} / \mathrm{min}$. Fractions were selected on the basis of absorbance at $254 \mathrm{~nm}$, and the material collected from each peak shown in Fig. 2 was collected and freeze-dried. Seven fractions were obtained (ND1-ND7).

Yeast fractions were examined by thin-layer chromatography in several systems: Polyamide $F_{254}$ plates (Merck) with sodium acetate in water $(100 \mathrm{~g} / \mathrm{l})$ as solvent; Kieselgel $F_{254}$ plates (Merck) and Kieselgel plates without fluorescent indicator using $n$ propanol--water-concentrated ammonia (66:33:1, by vol). Detection of compounds was by quenching of the fluorescent indicator, by staining with iodine vapour, by staining with ninhydrin and with naphthoresorcinol (Smith, 1969). 


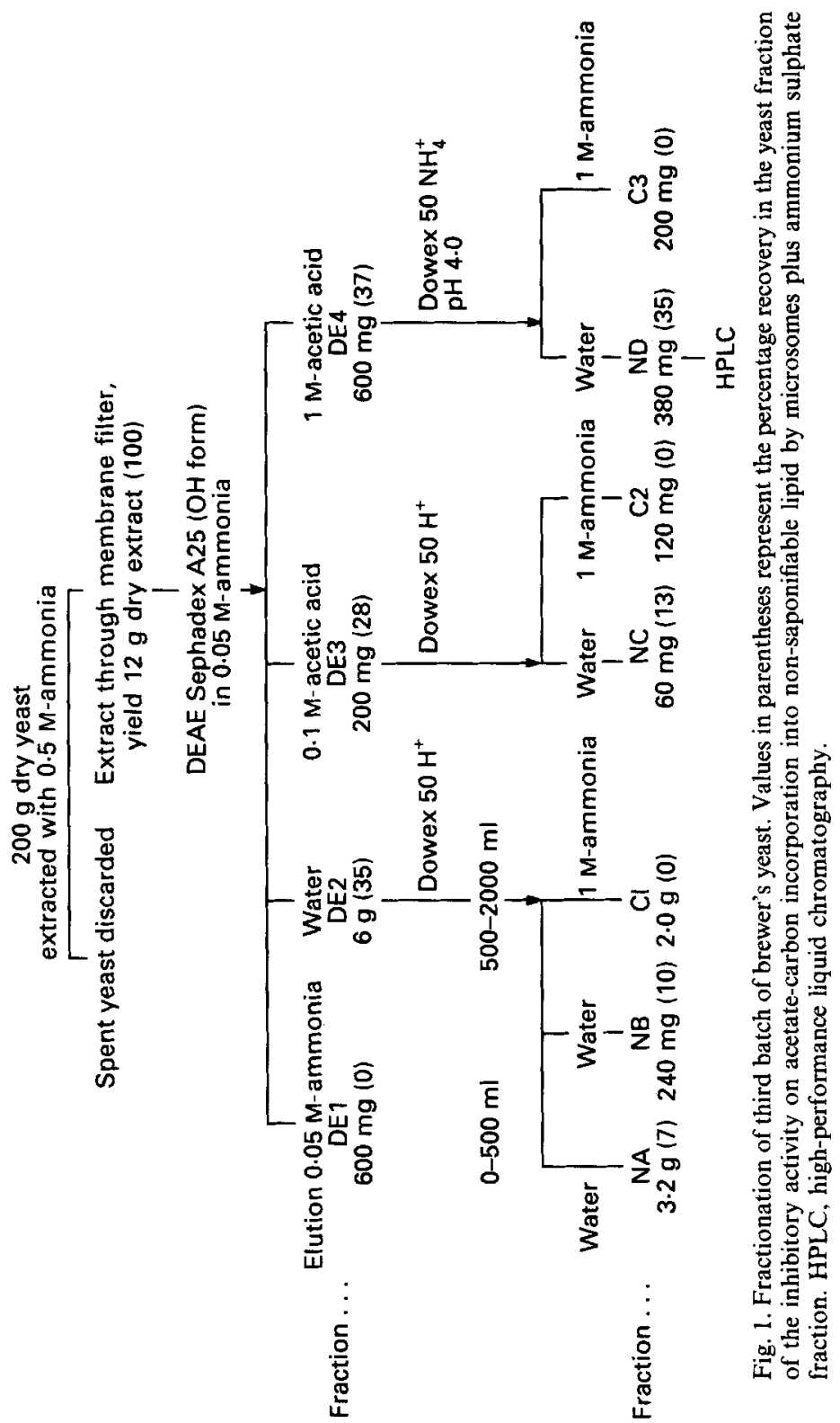




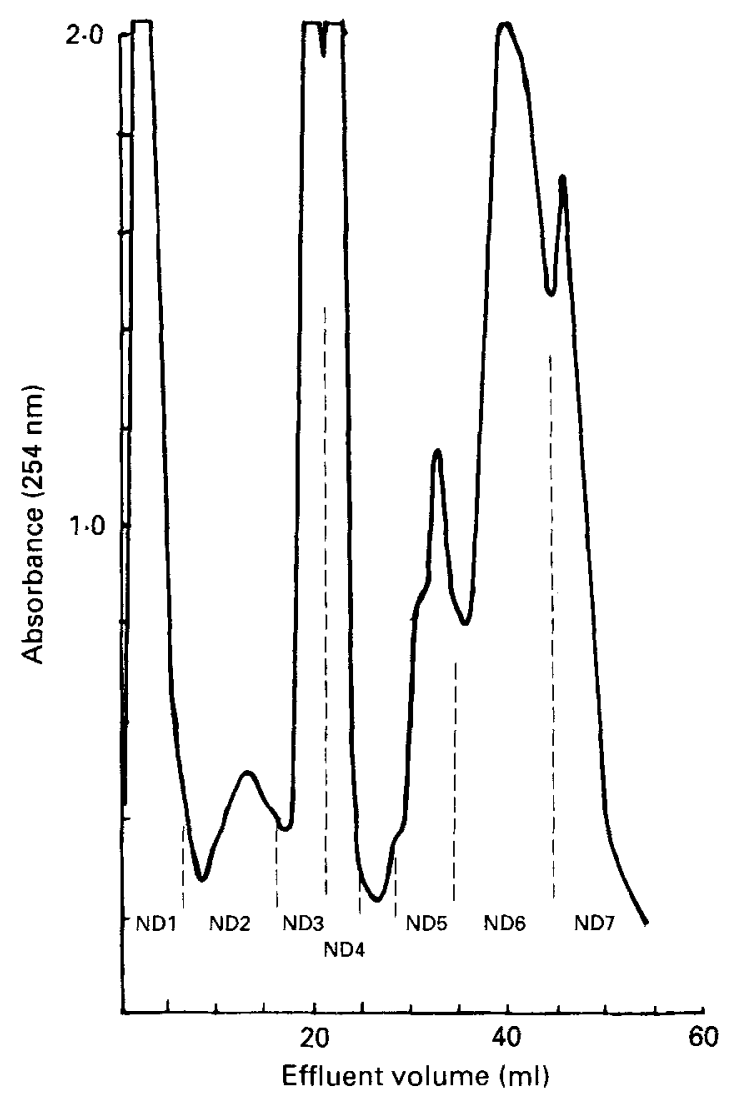

Fig. 2. High-performance liquid chromatography (HPLC) of fraction ND was performed as described on p. 286 Absorbance at $254 \mathrm{~nm}$ of effluent is shown. (-), The effluent was cut to give the seven fractions ND1-ND7.

\section{Treatment of $N A D H$ and $N A D P H$}

Portions $(10 \mathrm{mg}$ ) of each of the reduced nicotinamide nucleotides (Sigma Chemical Co, St Louis, USA) were dissolved in $200 \mathrm{ml} 0.5 \mathrm{M}$-ammonia solution and kept at $20^{\circ}$ for $2 \mathrm{~h}$ and then freeze-dried. The material was then dissolved in $100 \mathrm{ml} 1 \mathrm{M}$-acetic acid and kept at $20^{\circ}$ for $2 \mathrm{~h}$ and freeze-dried. The solids were dissolved in $5 \mathrm{ml}$ distilled water and stored at $-15^{\circ}$.

\section{Animals and diets}

Normal diet. Hooded Wistar male rats were raised from weaning on commercial rat cubes and water ad lib., at a minimum temperature of $20-22{ }^{\circ} \mathrm{C}$, and a minimum relative humidity of $40-45 \%$. Lighting was from 06.00 to 18.00 hours. Rats were used when they were approximately $200 \mathrm{~g}$ weight and were killed at approximately 09.00 hours.

Cholestyramine diet. Six rats were fed on crushed rat cubes mixed with cholestyramine, $30 \mathrm{~g} / \mathrm{kg}$, for the final $7-10 \mathrm{~d}$ before preparation of $10000 \mathrm{~g}$ supernatant fraction $\left(\mathrm{S}_{10}\right.$ fraction) or microsomes in order to maximize cholesterol synthesis. These rats were killed at midnight, instead of the usual 09.00 hours, in order to have the hydroxymethylglutaryl (HMG)-CoA reductase (EC 1.1.1.34) activity near its diurnal maximum.

Low-Cr diet. Rats were raised from weaning (about $50 \mathrm{~g}$ ) on the low-Cr diet supplied by Teklad (Wisconsin, USA) which contained $300 \mathrm{~g}$ Torula yeast $/ \mathrm{kg}, 600 \mathrm{~g}$ sucrose $/ \mathrm{kg}$, lard, vitamins, minerals and amino acids (Teklad 84485), and which contained less than $0 \cdot 1 \mu \mathrm{g}$ 
$\mathrm{Cr} / \mathrm{g}$ (Holdsworth \& Neville, 1990). To minimize contamination by $\mathrm{Cr}$ the rats were housed in plastic cages with raised aluminium-mesh floors and given deionized water to drink from all-glass containers. Room air was not filtered. Lighting was from 06.00 to 18.00 hours. The rats were used when they were approximately $200 \mathrm{~g}$ weight, after 7-8 weeks on the diet. Rats which had been reared on this diet were probably only marginally deficient in $\mathrm{Cr}$ (Schroeder, 1969), but adipocytes from rats reared in this way responded to yeast extracts (Davies et al. 1985) in the manner reported for Cr-complexes.

\section{Isolation and incubation of hepatocytes, extraction of lipids}

Hepatocytes were isolated from rats which had been fed on a normal diet, and were incubated as previously described (Holdsworth \& Neville, 1988). Incubation flasks contained $20 \mathrm{mg}$ dry weight of cells plus $20 \mathrm{~mm}$-glucose plus radioactive metabolites as shown in Table 1 (p. 292) in a total volume of $4 \mathrm{ml}$. When added $\left[1{ }^{14} \mathrm{C}\right]$ acetate was $1 \mathrm{~mm}$, $3 \times 10^{5}$ disintegrations $/ \mathrm{min}(\mathrm{dpm})$ per $\mathrm{ml} ;\left[2{ }^{3} \mathrm{H}\right]$ mevalonate was $0 \cdot 1 \mathrm{mM}, 7 \cdot 5 \times 10^{5} \mathrm{dpm}$ per $\mathrm{ml} ;{ }^{3} \mathrm{H}_{2} \mathrm{O}$ was $1 \times 10^{9} \mathrm{dpm}$ per $\mathrm{ml}$. When added, the yeast fraction was present at $250 \mu \mathrm{g} / \mathrm{ml}$. Reactions were stopped after 20,40 and $60 \mathrm{~min}$ by addition of perchloric acid $\left(\mathrm{HClO}_{4}\right)$ to give $0.3 \mathrm{M}$. Flask contents were centrifuged and the precipitate washed with $0.3 \mathrm{M}-\mathrm{HClO}_{4}$. The drained precipitate was suspended in $2 \mathrm{ml}$ water and $1 \mathrm{ml} 10 \mathrm{M}-$ potassium hydroxide and $5 \mathrm{ml}$ ethanol added. Saponification took place at $75^{\circ}$ for $90 \mathrm{~min}$. Non-saponified lipid was extracted with light petroleum (b.p. $40-60^{\circ}$ ), and after acidification of the aqueous layer with concentrated hydrochloric acid the fatty acids were extracted. The extracted lipids were placed in glass scintillation vials, taken to dryness in air and the radioactivity was measured.

\section{Preparation of $S_{10}$ and measurement of fatty acid and sterol synthesis}

Rat livers were homogenized and the supernatant fraction $\left(S_{10}\right)$ was obtained by centrifugation at $10000 \mathrm{~g}$ for $20 \mathrm{~min}$ at $4^{\circ}$ as described by Goodwin \& Margolis (1978). A $0.8 \mathrm{ml}$ portion of supernatant fraction containing approximately $30 \mathrm{mg}$ protein was preincubated at $37^{\circ}$ for $20 \mathrm{~min}$, with shaking at $100 \mathrm{rev} . / \mathrm{min}$, then $0.2 \mathrm{ml}$ of a mixture of cofactors (Goodwin \& Margolis, 1978) plus radioactive metabolites as shown in Table 2 (p. 292) was added, together with $25 \mu \mathrm{l}$ water or yeast extract. When added $\left[1-{ }^{14} \mathrm{C}\right]$ acetate was $2 \mathrm{mM}, 4 \times 10^{6} \mathrm{dpm}$ per $\mathrm{ml} ;\left[2-{ }^{14} \mathrm{C}\right]$ mevalonate $0.5 \mathrm{mM}, 2 \times 10^{5} \mathrm{dpm}$ per $\mathrm{ml}$; DL-[2$\left.{ }^{14} \mathrm{C}\right] \mathrm{HMG}-\mathrm{CoA} 0.33 \mathrm{~mm}, 3 \times 10^{5} \mathrm{dpm}$ per ml. Incubation was continued for various times up to $10 \mathrm{~min}$ at which time the reaction was stopped by addition of ice-cold $\mathrm{HClO}_{4}$ to give $0.6 \mathrm{M}$. Lipids were extracted from the precipitate and saponified as described previously. Non-saponifiable lipids were extracted and radioactivity was measured as described previously. Ten replicate samples of non-saponifiable lipids were fractionated by gas-liquid chromatography on columns of OV17 $(150 \mathrm{~g} / \mathrm{kg})$ on Chromosorb $\mathrm{G}$ at $270^{\circ}$.

$S_{10}$ preparations incorporated little acetate-C into non-saponifiable lipids unless the $S_{10}$ preparation had been pre-incubated at $37^{\circ}$. As already reported (Goodwin \& Margolis, 1978 ), the approximately 13-fold increase in incorporation which resulted from preincubation was presumably due to activation by dephosphorylation of the inactive, phosphorylated form of the rate-limiting enzyme HMG-CoA reductase, since it was abolished by including MgATP in the pre-incubation mixture or by inclusion of fluoride. Pre-incubation had no effect on incorporation of mevalonate.

Preparation of rat liver microsomes and supernatant fraction, and the synthesis of sterols Livers from rats fed on normal rat cubes (killed at 09.00 hours) or rats fed on the cholestyramine diet (killed at midnight) were used to prepare microsomes and also the fraction precipitating at $40-80$ percentage saturation with ammonium sulphate from the 
$105000 \mathrm{~g}$ supernatant fraction (arnmonium sulphate fraction) by the method of Kuroda \& Endo (1977). The preparations were stored in small portions at $-80^{\circ}$ and thawed as needed for incorporation of precursors into non-saponifiable lipids or for enzyme assays.

Incorporation experiments were performed as described by Kuroda \& Endo (1977). Incubation mixtures included microsomes $(0.18 \mathrm{mg}$ protein) plus ammonium sulphate fraction ( $1.7 \mathrm{mg}$ protein) plus cofactors and radioactive substrates in a total volume of $0.2 \mathrm{ml}$. When added $\left[1-{ }^{14} \mathrm{C}\right]$ acetate was $1 \mathrm{~mm}, 9 \times 10^{6} \mathrm{dpm}$ per $\mathrm{ml} ;\left[1{ }^{14} \mathrm{C}\right]$ acetyl-CoA was $0.1 \mathrm{~mm}, 1.3 \times 10^{6} \mathrm{dpm}$ per $\mathrm{ml} ;\left[2{ }^{14} \mathrm{C}\right]$ mevalonate was either $0.45 \mathrm{~mm}, 1.35 \times 10^{6} \mathrm{dpm}$ per ml or $35 \mu \mathrm{M}, 4.2 \times 10^{5} \mathrm{dpm}$ per $\mathrm{ml}$. Radioactivity was measured in the extracted nonsaponifiable lipid. Ten replicate samples of non-saponifiable lipids were fractionated by thin-layer chromatography using the method of Chang et al. (1979), and the distribution of ${ }^{14} \mathrm{C}$ on the plates was located with a spark chamber (Birchover Instruments, UK).

\section{Enzyme assays}

HMG-CoA synthetase (EC 4.1.3.5) and acetoacetyl-CoA thiolase (EC 2.3.1.9) activity of the ammonium sulphate fraction were estimated as described by Kurado \& Endo (1977).

HMG-CoA reductase was estimated in microsomes obtained in two ways. (1) Microsomes were isolated from $S_{10}$ preparations after incubation of $S_{10}$ at $37^{\circ}$ for $20 \mathrm{~min}$ to activate the enzyme. The activated $S_{10}$ was centrifuged as described by Ingebritson \& Gibson (1981) but at $20^{\circ}$ instead of $4^{\circ}$, the microsomes were resuspended and the enzyme assayed as described using NADP plus an NADPH-regenerating system. The HMG-CoA concentration was varied between 330 and $18 \mu \mathrm{M}$ with appropriate adjustment in incubation time. After acidification, lactonization and thin-layer chromatography, the products were revealed by staining the plates with $\mathrm{I}_{2}$ vapour and ${ }^{14} \mathrm{C}$ bands were detected with a spark chamber (Birchover Instruments). The $\left[{ }^{14} \mathrm{C}\right]$ mevalonolactone band was scraped off and counted in ACS II scintillation cocktail with thixotropic gel powder (Packard Instrument Co., USA) and ${ }^{14} \mathrm{C}$ recovered was corrected for recovery of the $\left[{ }^{3} \mathrm{H}\right]$ mevalonolactone internal standard. (2) HMG-CoA reductase was also assayed in microsomes prepared by the method of Kuroda \& Endo (1977) and assayed both at $5 \mathrm{~mm}-\mathrm{NADPH}$ and at $100 \mu \mathrm{M}-$ NADPH with appropriate decrease in incubation time.

Acetyl-CoA carboxylase (EC 6.4.1.2) was estimated in $\mathrm{S}_{10}$ preparations by the method of Holland et al. (1984). Glucose-6-phosphate dehydrogenase (EC 1.1.1.49) in $\mathrm{S}_{10}$ preparations was assayed spectrophotometrically (Lohr \& Waller, 1974).

\section{Total cholesterol and HDL-cholesterol}

Blood samples were taken at 10.00 hours from the abdominal aorta under light diethyl ether anaesthesia from animals which had been fasted overnight. Samples were allowed to clot for $2 \mathrm{~h}$ at $4^{\circ}$. Part of the serum was immediately treated with polethylene glycol 6000 $(100 \mathrm{~g} / 1)$ at $\mathrm{pH} 10$ for 5 min to precipitate low-density lipoproteins and very-low-density lipoproteins, and then centrifuged (Allen et al. 1979). The supernatant fraction was used for estimation of HDL-cholesterol, and untreated serum was used for estimation of total cholesterol. Cholesterol was estimated enzymically using a Boehringer Mannheim CHODPAP kit, using ALSP serum standard (CSL) and Validate Control.

\section{Miscellaneous}

Protein was estimated by the method of Lowry (Layne, 1957). Perirenal and epidydimal adipose tissue samples were placed, immediately after removal from the animal, in small air-tight containers and weighed within a few minutes. Radioactivity was measured in ACS II scintillation fluid (Packard Instrument Co., USA) in a Beckman 3801 multi-channel liquid scintillation counter appropriately programmed for quenching and for discrimination 
between ${ }^{3} \mathrm{H}$ and ${ }^{14} \mathrm{C}$. The significance of differences between means was calculated using Student's $t$ test.

\section{RESULTS}

Effect of yeast fraction NI on incorporation of precursors into lipids by hepatocytes Isolated hepatocytes incorporated $\mathrm{C}$ from $\left[1-{ }^{14} \mathrm{C}\right]$ acetate into non-saponifiable and saponifiable lipids, and yeast fraction N1 inhibited these processes equally (Table 1). Results were identical whether fraction $\mathrm{N} 1$ was obtained from low- or high-Cr yeast preparations. C from $\left[2-{ }^{14} \mathrm{C}\right]$ mevalonate was incorporated into non-saponifiable lipid (mean 0.71 (SE 0.01$) \mu \mathrm{mol} / \mathrm{h}$ per $\mathrm{g}$ dry weight) but at only about one-tenth the rate of incorporation of ${ }^{3} \mathrm{H}$ from $\left[2-{ }^{3} \mathrm{H}\right]$ mevalonolactone, perhaps due to a permeability phenomenon. Neither label was found in significant amounts in fatty acids. At the concentration used, fraction $\mathrm{N} 1$ did not inhibit incorporation of mevalonate or mevalonolactone into non-saponifiable lipid and had only a small effect on incorporation of tritium from tritiated water.

\section{Effect of fraction $\mathrm{N1}$ on incorporation of precursors by $S_{10}$ preparations}

Table 2 shows that $S_{10}$ preparations which had been activated by pre-incubation (see p. 289) incorporated acetate-C into non-saponifiable lipids. The non-saponifiable lipids gave only one peak on gas-liquid chromatography, and that peak had the same mobility as cholesterol. Fraction N1, prepared from yeast, inhibited incorporation of acetate-C into non-saponifiable lipids and the degree of inhibition was similar with extracts from high- or low-Cr yeast. The yeast fraction also inhibited the small incorporation into nonsaponifiable lipid by non-pre-incubated preparations but had no effect on the degree of activation achieved during pre-incubation. Yeast fraction $\mathrm{N} 1$ was a less effective inhibitor of mevalonate incorporation than of acetate incorporation. Results for the expensive substrate $\mathrm{HMG}-\mathrm{CoA}$ are derived from one experiment in which fraction $\mathrm{N} 1$ inhibited HMG-CoA incorporation by $80 \%$ while inhibition of acetate incorporation was within the normal range.

The cationic fractions from high- and low-Cr yeast had little inhibitory effect on acetate$\mathrm{C}$ incorporation into non-saponifiable lipid. Saponifiable lipids also were labelled after incubation of $\left[{ }^{14} \mathrm{C}\right]$ acetate with preparations from animals on normal and low-Cr diets $(0 \cdot 28$ (SE 0.02) and 0.32 (SE 0.03) $\mu \mathrm{mol} / \mathrm{h}$ per g protein respectively). Fraction N1 from high- and low-Cr yeast inhibited this incorporation somewhat less strongly than incorporation into non-saponifiable lipid; for example $250 \mu \mathrm{g}$ fraction $\mathrm{Nl} / \mathrm{ml}$ inhibited incorporation into non-saponifiable and saponifiable lipids by 50 and $34 \%$ respectively.

\section{Comparison of $S_{10}$ preparations from animals fed on normal and low-Cr diets}

$\mathrm{S}_{10}$ preparations from animals which had been reared on a low-Cr diet incorporated precursor-C into non-saponifiable lipids more slowly than did preparations from normal animals (Table 2) but the cause of this difference is not known. No difference was found in the glucose-6-phosphate dehydrogenase activity of normal- and low-Cr $\mathrm{S}_{10}$ preparations (Table 3), and the activity was much in excess of that needed to supply the NADPH needed for the observed rates of lipid synthesis. Fraction N1 did not inhibit glucose-6-phosphate dehydrogenase under these conditions. HMG-CoA reductase activities in microsomes isolated from $S_{10}$ preparations were similar in normal- and low-Cr preparations (Table 3), and the yields of microsomes from the two preparations were similar. There was no difference between these normal- and low-Cr rats in total serum cholesterol or in HDLcholesterol (Table 3). There were obvious differences in the amounts of perirenal fat and epidydimal fat (Table 3 ). 
Table 1. Effects of yeast fraction $N 1^{*}$ (high-chromium) on incorporation of precursors into lipids by hepatocytes from animals on a normal diet

(Values given are as means with their standard errors; no. of replicates five)

\begin{tabular}{|c|c|c|c|c|c|c|c|c|}
\hline & \multicolumn{4}{|c|}{$\begin{array}{l}\text { Basal incorporation rate } \\
\text { into lipids } \\
(\mu \mathrm{mol} / \mathrm{h} \text { per } \mathrm{g} \text { dry weight) }\end{array}$} & \multicolumn{4}{|c|}{$\begin{array}{l}\text { Percentage inhibition } \\
\text { by fraction } \mathrm{Nl}\end{array}$} \\
\hline & \multicolumn{2}{|c|}{ Non-sàponifiable } & \multicolumn{2}{|c|}{ Saponifiable } & \multicolumn{2}{|c|}{ Non-saponifiable } & \multicolumn{2}{|c|}{ Saponifiable } \\
\hline & Mean & $\mathrm{SE}$ & Mean & $\mathrm{SE}$ & Mean & $\mathrm{SE}$ & Mean & SE \\
\hline${ }^{3} \mathrm{H}, \mathrm{O}$ & $3 \cdot 7$ & $0 \cdot 4$ & $16 \cdot 7$ & $2 \cdot 3$ & 14 & 2 & $-2 I^{\dagger}$ & 6 \\
\hline$\left[1-{ }^{14} \mathrm{C}\right]$ acetate & $5 \cdot 0$ & $0 \cdot 3$ & $7 \cdot 0$ & $1 \cdot 1$ & 67 & 10 & 63 & 9 \\
\hline$\left[2-{ }^{3} \mathrm{H}\right]$ mevalonolactone & $7 \cdot 7$ & 0.4 & - & - & $-2 \dagger$ & 5 & - & 一 \\
\hline
\end{tabular}

* For details of fractionation procedure, see Fig. 1 and p. 286.

$\dagger$ This represents a stimulation of incorporation.

Table 2. Effect of yeast fraction N1 $\dagger$ from high-or low-chromium yeast on incorporation of precursor-carbon into non-saponifiable lipids by $S_{10}$ preparations $\ddagger$ from animals fed on normal or low-Cr diets\$

(Values are given as means with their standard errors; no. of replicates six, except for the hydroxymethylglutaryl-COA (HMG-CoA) values which are based on only two estimates)

\begin{tabular}{|c|c|c|c|c|c|c|}
\hline \multirow{2}{*}{$\begin{array}{l}\text { Fraction } \mathrm{Nl} \\
\text { yeast }(\mu \mathrm{g} / \mathrm{ml})\end{array}$} & \multirow[b]{2}{*}{ Diet } & \multicolumn{2}{|c|}{$\left[1-{ }^{14} \mathrm{C}\right]$ acetate } & \multicolumn{2}{|c|}{$\left[2-{ }^{14} \mathrm{C}\right]$ mevalonate } & \multirow[b]{2}{*}[2-{}^{14}\mathrm{C}]{$\mathrm{HMG}-\mathrm{CoA}$} \\
\hline & & Mean & $\mathrm{SE}$ & Mean & SE & \\
\hline \multicolumn{7}{|c|}{ Basal incorporation rate $(\mu \mathrm{mol} / \mathrm{h}$ per g protein): } \\
\hline & Normal & 0.84 & $0 \cdot 12$ & $5 \cdot 58$ & 0.90 & $0 \cdot 09,0 \cdot 13$ \\
\hline & Low-Cr & $0 \cdot 31^{*}$ & 0.05 & $2 \cdot 80^{*}$ & 096 & $-\quad-$ \\
\hline \multicolumn{7}{|c|}{$\begin{array}{l}\text { Percentage inhibition by fraction } \mathrm{N} 1 \text { : } \\
\text { Low-Cr }\end{array}$} \\
\hline 500 & Normal & 63 & 5 & 23 & 3 & $-\quad-$ \\
\hline 250 & Normal & 50 & 4 & 15 & 7 & 83,81 \\
\hline 100 & Normal & 40 & 3 & 0 & 3 & $-\quad-$ \\
\hline \multicolumn{7}{|l|}{ Low-Cr } \\
\hline 500 & Low-Cr & 53 & 1 & 2 & 3 & - \\
\hline 100 & Low-Cr & 21 & 3 & - & - & - \\
\hline \multicolumn{7}{|l|}{ High-Cr } \\
\hline 500 & Normal & 54 & 2 & - & - & - \\
\hline 100 & Normal & 29 & 3 & - & - & $-\quad-$ \\
\hline
\end{tabular}

Mean values were significantly different from those found on the normal diet: ${ }^{*} P<0 \cdot 0$ l.

$\uparrow$ For details of fractionation procedure, see Fig. 1 and p. 286.

For details of procedures, see p. 289.

For details of dietary treatments, see p. 288 and 289.

\section{Purification and identification of inhibitory material}

Thin-layer chromatography of fraction N1 showed eight components by $\mathrm{I}_{2}$-vapour staining, and six of these showed absorption of u.v. light $(254 \mathrm{~nm})$. Attempts to purify the inhibitory material by preparative thin-layer chromatography on Kieselgel using $n$ propanol--water $(66: 33, \mathrm{v} / \mathrm{v})$ were only partially successful since small amounts of dissolved silica present in zones eluted from the plates were inhibitory in the $S_{10}$ assay system. However two zones, $R_{F} 0.27$ and $0 \cdot 38$, showed marked inhibition in the $S_{10}$ assay 
Table 3. Comparison of preparations from rats fed on normal and low-chromium diets $\dagger$

(Values are given as means with their standard errors; no. of replicates ten, except for the value for glucose-6-phosphate dehydrogenase $(E C 1.1 .1 .49)$ activity which is based on three replicates, and the $K_{m}$ which was cstimated only once)

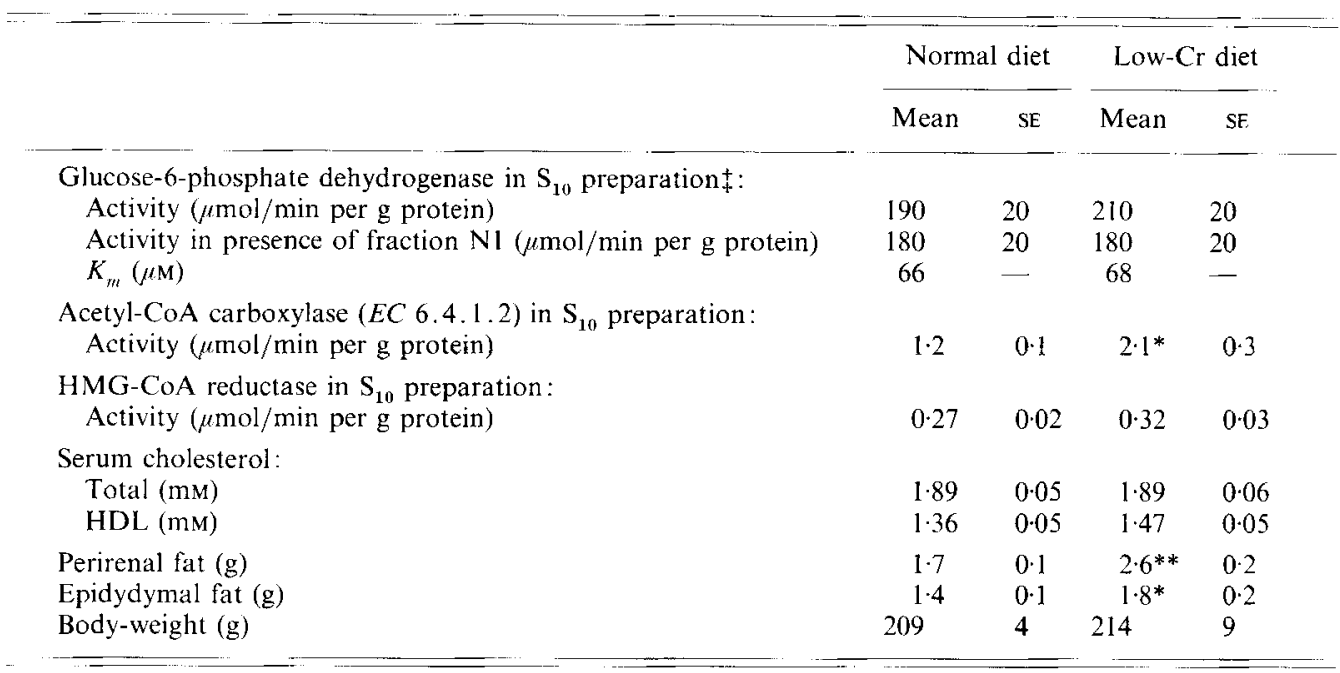

HMG-CoA, hydroxymethylglutaryl-CoA; HDL, high-density lipoprotein.

Mcan values were significantly different from those of animals on normal diet: $* P<0.05, \quad * * P<0.01$.

$\dagger$ For details of dietary treatments, see pp. 288 and 289.

¥ For details of procedures, see p. 289.

system. These zones stained positive for carbohydrate with naphthoresorcinol, and after elution were found to absorb at $259-262 \mathrm{~nm}$. Further purification of the inhibitory material was attempted using a third batch of brewer's yeast which was fractionated as shown in Fig. 1

As results with $S_{10}$ preparations were rather variable from one preparation to another, the source of enzymes for the assay system was changed to microsomes plus ammonium sulphate fraction which could be stored at $-80^{\circ}$ without loss of activity. Table 4 shows that fraction $\mathrm{N} 1$ from the low-Cr yeast was more inhibitory to the incorporation of $\mathrm{C}$ from [1${ }^{14} \mathrm{C}$ ]acetyl-CoA than to the incorporation of mevalonate- $\mathrm{C}$ into non-saponifiable lipid by this microsomal preparation. Thin-layer chromatography of the non-saponifiable fractions showed that the ${ }^{14} \mathrm{C}$ was distributed between cholesterol, methyl sterols, squalene 2,3-oxide and squalene. When ${ }^{14} \mathrm{C}$ incorporation from acetyl-CoA or mevalonate was decreased by fraction $\mathrm{N} 1$, the percentage distribution of ${ }^{14} \mathrm{C}$ between these components was not altered. Fractions NB, NC and ND from the third batch of yeast (Fig. 1) were inhibitory to the incorporation of $\mathrm{C}$ from acetate or acetyl-CoA, but had a smaller effect on mevalonate incorporation (Table 4). None of the cationic fractions $\mathrm{C} 1, \mathrm{C} 2$ or C3 (Fig. 1) was inhibitory.

Examination of fractions NA, NB, NC and ND by thin-layer chromatography gave complex chromatograms but the eight zones found in $\mathrm{N} 1$ were common to all, although the proportions of the zones were not the same. Recourse was made to high-performance liquid chromatography to purify ND (Fig. 2) and seven fractions ND1-ND7 were obtained. The main inhibitory activity was found in ND2 and ND3. These fractions were examined by mass spectrometry and by proton and ${ }^{13} \mathrm{C}$ NMR. ND2 was found to be nicotinamide $\beta$ ribofuranoside. The u.v. spectrum of ND2 showed an absorption peak at $266 \mathrm{~nm}$, consistent with this structure, and the absorption was shifted to $326 \mathrm{~nm}$ by $1 \mathrm{M}$-potassium 
Table 4. Effects of yeast fractions* on incorporation of substrate-carbon into nonsaponifiable lipid by microsomes plus ammonium sulphate fraction $\dagger$

(Values are given as means with their standard errors)

\begin{tabular}{|c|c|c|c|c|c|c|c|c|c|c|}
\hline \multirow{3}{*}{\multicolumn{2}{|c|}{$\begin{array}{l}\text { Substrate... } \\
\text { Enzymef }\end{array}$}} & \multirow[b]{3}{*}{$n$} & \multirow{2}{*}{\multicolumn{2}{|c|}{$\frac{\left[1-{ }^{14} \text { C }\right] \text { acetate }}{N}$}} & \multirow{2}{*}{\multicolumn{2}{|c|}{$\frac{\left[1-{ }^{14} \mathrm{C}\right] \text { acetyl-CoA }}{\mathrm{C}}$}} & \multicolumn{4}{|c|}{$\left[2-{ }^{14} \mathrm{C}\right]$ mevalonate } \\
\hline & & & & & & & \multicolumn{2}{|c|}{$35 \frac{t \mathrm{M}}{\mathrm{N}}$} & \multicolumn{2}{|c|}{$\begin{array}{c}450 \mu \mathrm{M} \\
\mathrm{C}\end{array}$} \\
\hline & & & Mean & SE & Mean & SE & Mean & SE & Mean & $\mathrm{SE}$ \\
\hline \multicolumn{11}{|c|}{ Basal incorporation rate ( $\mu \mathrm{mol} / \mathrm{h}$ per $\mathrm{g}$ total protein) } \\
\hline & & 6 & 0.46 & $0 \cdot 03$ & - & - & $2 \cdot 4$ & $0 \cdot 1$ & - & - \\
\hline & & 8 & - & - & 0.73 & 0.08 & - & - & $6 \cdot 1$ & $0 \cdot 2$ \\
\hline \multicolumn{11}{|c|}{ Percentage inhibition by yeast fractions or treated nicotinamide nucleotide $(\mathrm{mg} / \mathrm{ml})$ : } \\
\hline \multirow[t]{2}{*}{$\mathrm{N1}:$} & $2-0$ & 6 & - & - & 56 & 3 & - & - & 20 & 2 \\
\hline & 1.0 & 4 & 一 & - & 49 & 1 & - & - & - & - \\
\hline $\mathrm{NA}$ & 20 & 6 & 0 & 2 & - & - & 0 & 3 & - & - \\
\hline NB & $0-4$ & 6 & 44 & 7 & - & - & 0 & 4 & - & - \\
\hline $\mathrm{NC}$ & $0 \cdot 3$ & 6 & 34 & 5 & - & - & 16 & 12 & - & - \\
\hline \multirow[t]{2}{*}{ ND: } & 1.5 & 6 & - & - & 100 & 1 & 11 & 4 & - & - \\
\hline & 0.5 & 4 & 37 & 10 & - & - & 5 & 3 & - & - \\
\hline NDI & $9 \cdot 0 \S$ & 4 & 95 & 4 & 67 & 11 & - & - & - & - \\
\hline \multirow[t]{2}{*}{$\mathrm{ND} 2$ : } & $0.2 \S$ & 4 & 98 & 1 & 99 & 1 & - & - & - & - \\
\hline & 0.05 & 4 & 55 & 3 & - & - & - & - & - & - \\
\hline \multirow[t]{2}{*}{ ND3: } & $1 \cdot 2 \S$ & 4 & 74 & 14 & 99 & 1 & - & - & - & - \\
\hline & $0 \cdot 3$ & 4 & 44 & 4 & - & - & - & - & - & - \\
\hline ND4 & $0.9 \S$ & 4 & 8 & 2 & 48 & 3 & $\ldots$ & - & - & - \\
\hline ND5 & $0.2 \S$ & 4 & 7 & 3 & 63 & 1 & - & - & - & - \\
\hline ND6 & $6-8 \$$ & 4 & 12 & 4 & - & - & - & - & - & - \\
\hline ND7 & $0.8 \S$ & 4 & 15 & 3 & 26 & 8 & - & - & - & - \\
\hline \multicolumn{11}{|c|}{ Treated NADH } \\
\hline & 0.4 & 2 & - & - & & & - & - & - & - \\
\hline \multicolumn{11}{|c|}{ Treated NADPH } \\
\hline & $0-4$ & 2 & - & - & & & - & - & - & 一 \\
\hline
\end{tabular}

$\mathrm{N}$, animals fed on normal diet; $\mathrm{C}$, animals fed on cholestyramine diet; $n$, number of replicates

* For details of fractionation procedure, see Fig. 1 and p. 286.

+ For details of fractionation procedure, see pp. 289 and 290.

$\$$ For details of dietary treatments and extraction procedures, see pp. $288-290$.

$\S$ Amounts are proportional to the yield from high-performance liquid chromatography.

cyanide, showing the presence of the positively charged aromatic nitrogen atom. Fraction ND3, absorption maximum at $277 \mathrm{~nm}$, showed only a small shift with KCN. This fraction was much less active on a weight basis than fraction ND2, and may have been contaminated with nicotinamide riboside due to the difficulty of matching exactly the collection of column effluent samples to the troughs of absorption at $254 \mathrm{~nm}$. Treatment of NADH and NADPH with dilute ammonia, followed by dilute acetic acid, produced inhibitory material (Table 4) providing further support for the conclusion that one of the inhibitory materials was a nicotinamide derivative.

Attempt to find the mechanism of inhibitory action of yeast fractions

In all three assay systems, hepatocytes, $\mathrm{S}_{10}$ and microsomes plus ammonium sulphate fraction, the relative rates of incorporation of substrate atoms and degree of inhibition by yeast fractions were consistent with $\mathrm{HMG}-\mathrm{CoA}$ reductase being the rate-limiting enzyme and site of inhibition by yeast fractions. However $\mathrm{HMG}-\mathrm{CoA}$ reductase activity in 
Table 5. Hydroxymethylglutaryl-CoA (HMG-CoA) reductase (EC 1.1.1.34) activity in microsomes isolated from livers of animals on various diets*, in the presence or absence of yeast fraction $\mathrm{Nl} \uparrow$

(Values are given as means with their standard errors; no. of replicates four)

\begin{tabular}{|c|c|c|c|c|c|c|}
\hline \multirow[b]{3}{*}{ Diet } & \multirow{2}{*}{\multicolumn{2}{|c|}{ Substrate }} & \multicolumn{4}{|c|}{$\begin{array}{c}\mathrm{HMG}-\mathrm{CoA} \text { reductase activity } \\
(\mu \mathrm{mol} / \mathrm{min} \text { per } \mathrm{g} \text { microsomal protein })\end{array}$} \\
\hline & & & \multicolumn{2}{|c|}{ Without fraction $\mathrm{Nl}$} & \multicolumn{2}{|c|}{ With fraction $\mathrm{Nl}$} \\
\hline & $\begin{array}{l}\text { HMG-CoA } \\
\quad(\mu \mathrm{M})\end{array}$ & $\begin{array}{l}\text { NADPH } \\
(\mathrm{mm})\end{array}$ & Mean & SE & Mean & $\mathrm{SE}$ \\
\hline Cholestyraminef & $\begin{array}{r}330 \\
330 \\
33\end{array}$ & $\begin{array}{l}5 \\
0 \cdot 1 \\
4\end{array}$ & $\begin{array}{l}1 \cdot 19 \\
1 \cdot 11 \\
0 \cdot 75\end{array}$ & $\begin{array}{l}0.03 \\
0.08 \\
0 \cdot 15\end{array}$ & $\begin{array}{l}1.30 \\
1.28 \\
0.74\end{array}$ & $\begin{array}{l}0.08 \\
0.13 \\
0.15\end{array}$ \\
\hline Cholestyramine $\$$ & 330 & $3^{\|}$ & $1 \cdot 45$ & 0.23 & $1 \cdot 31$ & $0 \cdot 15$ \\
\hline Normal & $\begin{array}{r}330 \\
33\end{array}$ & $\begin{array}{l}3^{\|} \\
3^{\|}\end{array}$ & $\begin{array}{l}0.27 \\
0 \cdot 15\end{array}$ & $\begin{array}{l}0.02 \\
0 \cdot 01\end{array}$ & $\begin{array}{l}0 \cdot 26 \\
0 \cdot 18\end{array}$ & $\begin{array}{l}0 \cdot 01 \\
0 \cdot 01\end{array}$ \\
\hline Low-chromium & 330 & $3^{\|}$ & 0.32 & 0.03 & $0 \cdot 31$ & $0 \cdot 03$ \\
\hline
\end{tabular}

* For details of dietary treatments, see pp. 288 and 289.

$\dagger$ For details of fractionation procedures, see Fig. 1 and p. 286.

\$ Microsomes prepared by the method of Kuroda \& Endo (1977).

$\S$ Microsomes prepared from $S_{10}$ preparation.

$\|$ NADP plus NADPH regenerating system.

microsomes isolated from cholestyramine-fed animals was not inhibited in the presence of fraction $\mathrm{N} 1$ either at saturating or at rate-limiting HMG-CoA concentrations, or at $5 \mathrm{~mm}$ or $100 \mu \mathrm{M}-\mathrm{NADPH}$ (Table 5). Using microsomes isolated from $\mathrm{S}_{10}$ preparations from normal animals, maximum velocity $\left(V_{\max }\right)$ was lower than in microsomes from cholestyramine-fed animals, but no inhibition was seen in the presence of fraction N1 either at $V_{\max }$ or at rate-limiting concentrations of $\mathrm{HMG}-\mathrm{CoA}$.

HMG-CoA synthase and thiolase activities of the ammonium sulphate fraction were 0.85 and $0.44 \mu \mathrm{mol} / \mathrm{min}$ per $\mathrm{g}$ protein respectively, and were not inhibited by concentrations of fraction N1 which inhibited acetate incorporation into non-saponifiable lipid.

\section{DISCUSSION}

Incorporation of ${ }^{3} \mathrm{H}$ from tritiated water into hepatocyte lipid represents the rate of lipid synthesis from endogenous substrates in the presence of glucose. Lakshman \& Veech (1977) calculated that $1.24 \mu \mathrm{mol}$ acetyl units were incorporated into cholesterol per $\mu \mathrm{g}$ atom tritium incorporated from water; thus the observed ${ }^{3} \mathrm{H}_{2} \mathrm{O}$ incorporation into nonsaponifiable lipid (Table 1) corresponds to incorporation of $9 \cdot 0 \mu \mathrm{mol}$ acetyl units $/ \mathrm{h}$ per $\mathrm{g}$ dry weight. This is in fair agreement with the value for incorporation of added $\left[{ }^{14} \mathrm{C}\right]$ acetate in the presence of unlabelled substrates, whereas the value for the $C_{6}$ precurser, mevalonolactone, is equivalent to a much greater rate of incorporation of acetyl units. Also for cell-free preparations (Tables 2 and 4) relative rates of incorporation of the $\mathrm{C}_{2}$ precursors, acetate and acetyl-CoA, compared with the $\mathrm{C}_{6}$ precursor, mevalonate, are consistent with the rate-limiting step being between acetyl-CoA and mevalonate. Results of the one experiment using HMG-CoA as substrate suggest that it was between HMG-CoA and mevalonate, i.e. at the step catalysed by HMG-CoA reductase.

Yeast fraction N1 had a small inhibitory effect on incorporation by hepatocytes of tritium from tritiated water into non-saponifiable lipid, no effect on incorporation of 
mevalonate or mevalonolactone, but strongly inhibited incorporation of acetate-C (Table 1). Lakshman \& Veech (1977) showed that $66 \%$ of the ${ }^{3} \mathrm{H}$ incorporated into cholesterol from tritiated water was incorporated in steps after mevalonate, therefore these results are consistent with an effect of fraction $\mathrm{N} 1$ on the early part of the pathway between acetate and mevalonate. Results with cell-free preparations (Tables 2 and 4) support this conclusion, and the purer fractions from the third batch of yeast had relatively less inhibitory effect on melavonate incorporation than did fraction N1.

Nevertheless attempts to detect inhibition by fraction N1 of HMG-CoA reductase in microsomes were unsuccessful. Yeast fraction N1 was not competitive with HMG-CoA even at rate-limiting concentrations of HMG-CoA (Table 5). Neither were attempts to detect any kind of competition with NADPH successful. The lowest NADPH concentration used was $100 \mu \mathrm{M}$ which is less than the $\mathrm{S}_{0.5}$ of the native microsomal enzyme, $234 \mu \mathrm{M}$ (Ness et al. 1986). However, lowering the concentration of NADPH to $100 \mu \mathrm{M}$ did not decrease the specific activity of these preparations, so that the enzyme may have been in a proteolytically modified form for which the $\mathrm{S}_{0.5}$ for NADPH is reported to be only $38 \mu \mathrm{M}$ under the conditions used (Ness et al. 1986). Allosteric regulation of HMG-CoA reductase is complex (Roitelman \& Schecter, 1984, 1986), and it may be that the failure to observe inhibition of the enzyme was related to the use of dithiothreitol in the enzyme assays whereas glutathione was the reducing agent for the incorporation experiments with $S_{10}$ and microsomes (Tables 2 and 4) and also presumably in intact cells (Table 1). As the purest yeast fraction obtained, ND2, appears to be nicotinamide riboside, competition with NADPH would be a feasible mechanism of inhibition. It may be significant that concentrations of fraction ND2 higher than those shown in Table 4 inhibited mevalonate incorporation into non-saponifiable lipid, possibly at the later NADPH-dependent steps. Inhibition of fatty acid synthesis by fraction N1 may have a similar cause. A careful study of effects of yeast fractions on $S_{10}$ preparations indicated that the yeast fractions were not affecting the degree of activation of the preparation during pre-incubation and, therefore, presumably not affecting dephosphorylation of phosphorylated $\mathrm{HMG}-\mathrm{CoA}$ reductase or reversal of cold inactivation. The cytosolic acetoacetyl-CoA thiolase and HMG-CoA synthase, which are the first steps in the pathway of conversion of acetyl-CoA to sterols, were not inhibited by yeast fractions under the conditions used, nor was glucose-6phosphate dehydrogenase. The possibility of effects on HMG-CoA lyase has not been excluded.

No evidence was found to support the contention that $\mathrm{Cr}$ may aid the lowering of blood cholesterol levels. In the present paper total cholesterol and HDL-cholesterol levels of serum were found to be identical in rats reared on normal- and low-Cr diets. However, these rats had been on the low $\mathrm{Cr}$ diet for only about 7 weeks which may not have been long enough for serum lipid abnormalities to develop (Schroeder, 1969), although abnormalities in body fat deposition were found (Table 3). Surprisingly, the basal rate of incorporation of acetate- $\mathrm{C}$ and mevalonate- $\mathrm{C}$ into non-saponifiable lipids was lower than normal in $\mathrm{S}_{10}$ preparations from low-Cr animals (Table 2), although the rate of incorporation of acetate into fatty acids was in the normal range. Estimates of HMG-CoA reductase and glucose-6-phosphate dehydrogenase have not explained this difference. Torula yeast provided a substantial part of the low-Cr diet and, like brewer's yeast, has been found to lower cholesterol levels in elderly patients (Offenbacher \& Pi-Sunyer, 1980). The Torula-yeast diet was originally found to produce necrotic liver degeneration in rats (Schwarz, 1951) and the resulting defects were prevented by giving vitamin E. That diet was subsequently found to be low in Cr (Schwarz \& Mertz, 1959), but other workers who have used a low-Cr diet based on casein and sucrose were unable to find an effect of the diet on plasma cholesterol (Donaldson et al. 1985). Possibly the Torula-yeast diet may cause a decrease in cholesterol synthesis in rat liver in vivo and in vitro, but in the present study 
it did not alter the blood cholesterol levels during the 7-week period in which the rats were exposed to the diet.

The other approach to the question of $\mathrm{Cr}$ effects on blood lipids, i.e. comparison of inhibitory effects of fractions derived from low- and high-Cr yeast preparations, has not revealed any difference in potency for inhibition of liver cholesterol synthesis in vitro. Thus, although the experiments reported here have shown the presence in yeast extracts of substances which inhibit liver cholesterol synthesis in vitro, there is no indication of any involvement of $\mathrm{Cr}$ in this process. It is possible that $\mathrm{Cr}$ may affect blood cholesterol levels at some other site in the complex system for regulation of cholesterol levels (Brown \& Goldstein, 1986). In previous investigations from this laboratory, no role for Cr could be found in the metabolism of glucose by adipocytes (Davies et al. 1985) or by hepatocytes (Holdsworth \& Neville, 1990).

In the present paper it has been shown that extracts of yeast contain an analogue of nicotinamide nucleotides, specifically nicotinamide riboside, which inhibits incorporation of acetyl groups into non-saponifiable lipid in vitro. It has been known for some time that commercial supplies of nicotinamide nucleotides, usually prepared from yeast, contain impurities which inhibit alcohol and lactate dehydrogenases (Bernofsky \& Gallacher, 1975; Loesche et al. 1980). It seems likely that these impurities could interfere with other enzymes requiring nicotinamide nucleotides such as those involved in synthesis of sterols and fatty acids. By deliberately exposing NADPH to alkali and acid we produced inhibitory material (Table 4). Such materials may have been present in the brewer's yeast used in clinical trials or may have been produced during intestinal digestion of nicotinamide nucleotides present in the yeast.

Another substance presence in yeast is pantethine (the disulphide of pantotheine) which has been reported to inhibit cholesterol and fatty acid synthesis (Ranganathan et al. 1982; Cighetti et al. 1986). The reported effects of pantethine differed from those of the factor reported in the present paper, since although it inhibited incorporation of acetate into cholesterol it increased incorporation into methyl sterols, thus placing the site of inhibition beyond squalene. In the present work spectroscopic evidence was obtained that pantethine was present in the fractions NA and NB. Thus, yeast appears to contain a number of substances which inhibit cholesterol synthesis by liver preparations in vitro and may contribute to the reported lowering of blood cholesterol by dietary yeast supplements. However, these factors are different from the substances that aid the utilization of a glucose load (Holdsworth \& Neville, 1988).

This work was supported by a grant from the CSIRO Industrial and Equity Fund. The third batch of yeast was prepared by E.S.H. while a guest of Dr P. Buckley, Massey University, Palmerston North, New Zealand, and the high-performance liquid chromatography was done by $\mathrm{Mr} \mathrm{D}$. Doll of that University. Identification of nicotinamide riboside by nuclear magnetic resonance and mass spectrometry was the work of Dr I. C. Burgar and Dr N. Davies of the Central Sciences Laboratory, University of Tasmania, to whom the authors express their gratitude.

\section{REFERENCES}

Abraham, A. S., Sonnenblick, M. \& Eini, M. (1982). The effect of chromium on cholesterol-induced atherosclerosis in rabbits. Atherosclerosis 41, 371-379.

Allen, J. K., Hensley, W. J., Nicholls, A. V. \& Whitfield, J. B. (1979). An enzymic and centrifugal method for estimating high-density lipoprotein cholesterol. Clinical Chemistry 25, 325-327.

Bernofsky, C. \& Gallacher, W. J. (1975). Lipid chromatography of pyridine nucleotides and associated compounds and isolation of several analogues of NADP. Analytical Biochemistry 67, 611-624.

Bourn, D. M., Gibson, R. S., Martinez, O. B. \& MacDonald, A. C. (1986). The effect of chromium supplementation on serum lipid levels in a selected sample of Canadian post-menopausal women. Biological Trace Element Research 9, 197-205. 
Brown, M. S. \& Goldstein, J. L. (1986). A receptor-mediated pathway for cholesterol homeostasis. Science 232, $34-47$.

Chang, T. Y., Schiavoni, E. S. \& McCrae, K. R. (1979). Inhibition of cholesterol biosynthesis in chinese hamster ovary by 4,4,10-trimethyl-trans-decal-3-ol. Journal of Biological Chemistry 254, $11258-11263$.

Cighetti, G., Del Puppo, M., Paroni, R., Galli, G. \& Galli Kienle, M. (1986). Effects of pantethine on cholesterol synthesis from mevalonate in isolated rat hepatocytes. Atherosclerosis 60, 67-77.

Conri, C. I., Simonoff, M., Besse, P., Llabador, Y., Fleury, B. \& Simonoff, G. N. (1986). Baise du chrome plasmatique au cours des coronaropathies. La Presse Médicale 15, 1931.

Davies, D., Holdsworth, E. S. \& Sherriff, J. L. (1985). The isolation of glucose tolerance factors from brewer's yeast and their relationship to chromium. Biochemical Medicine 33, 297-311.

Donaldson, D. L., Lee, D. M., Smith, C. C. \& Rennert, O. M. (1985). Glucose tolerance and plasma lipid distributions in rats fed a high-sucrose, high-cholesterol, low-chromium diet. Metabolism 34, 1086-1093.

Elwood, J. C., Nash, D. T. \& Streeton, D. H. P. (1982). Effect of high-chromium brewer's yeast on human serum lipids. Journal of the American College of Nutrition 1, 263-274.

Goodwin, C. D. \& Margolis, S. (1978). Cyclic AMP-sensitive activation of hepatic sterol synthesis and 3-hydroxy3-methylglutaryl coenzyme A reductase. Journal of Lipid Research 19, 747-756.

Grant, A. P. \& McMullen, J. K. (1982). The effect of brewer's yeast containing glucose tolerance factor on the response to treatment in type 2 diabetics. A short controlled study. Ulster Medical Journal 51, 110-114.

Holdsworth, E. S. \& Neville, E. (1988). Extracts of brewer's yeast contain GABA which enhances activation of glycogen synthetase by insulin in isolated rat hepatocytes. Biochemistry International 17, 1107-1116.

Holdsworth, E. S. \& Neville, E. (1990). Effects of extracts of high- and low-chromium brewer's yeast on metabolism of glucose by hepatocytes from rats fed on high- or low-chromium diet. British Journal of Nutrition 63, 623-630.

Holland, R., Witters, L. A. \& Hardie, G. (1984). Glucagon inhibits fatty acid synthesis in isolated hepatocytes via phosphorylation of acetyl CoA carboxylase by cyclic-AMP-dependent protein kinase. European Journal of Biochemistry 140, 325-333.

Hunt, A. E., Alan, K. G. D. \& Smith, B. A. (1985). Effect of chromium supplementation on hair chromium concentration and diabetic status. Nutrition Research 5, 131-140.

Ingebritson, T. S. \& Gibson, D. M. (1981). Assay of enzymes that modulate S-3-hydroxy-3-methylglutaryl-CoA reductase by reversible phosphorylation. Methods in Enzymology 71, 486 497.

Kuroda, M. \& Endo, A. (1977). Inhibition of in vitro cholesterol synthesis by fatty acids. Biochimica et Biophysica Acta 486, 70-81.

Lakshman, M. R. \& Veech, R. L. (1977). Measurement of rate of rat liver sterol synthesis in vivo using tritiated water. Journal of Biological Chemistry 252, 4667-4673.

Layne, E. (1957). Spectrophotometric and turbidimetric methods for measuring proteins. Methods in Enzymology 3, $447-454$.

Li, Y.-C. \& Stoecker, B. J. (1986). Chromium and yoghurt effects on hepatic lipid and plasma glucose and insulin of obese mice. Biological Trace Element Research 9, 233-242.

Loesche, W., Wenz, I., Till, U., Petermann, H. \& Horn, A. (1980). Purification of commercial NADH. Methods in Enzymology 66, 11-22.

Lohr, G. H. \& Waller, H. D. (1974). Methods for determination of enzymic activity: glucose-6-phosphate dehydrogenase. In Methods of Enzymatic Analysis, vol. 2, pp. 636-643. [H. U. Bergmeyer, editor]. New York: Academic Press.

Miller, N. E., Forde, O. H., Thelle, D. S. \& Mjos, O. D. (1977). The Tromso heart study. High density lipoprotein and coronary heart disease: a prospective case-control study. Lancet i, 965-968.

Ness, G. C., Sample, C. E., Smith, M., Pendleton, L. C. \& Eicher, D. C. (1986). Characteristics of rat liver microsomal 3-hydroxy-3-methylglutaryl coenzyme A reductase. Biochemical Journal 233, 167-172.

Newman, H. A. I., Leighton, R. F., Lanese, R. R. \& Freedland, N. A. (1978). Serum chromium and angiographically determined coronary artery disease. Clinical Chemistry 24, 541-544.

Offenbacher, E. G. \& Pi-Sunyer, F. X. (1980). Beneficial effect of chromium-rich yeast on glucose tolerance and blood lipids in elderly subjects. Diabetes 29, 919-925

Offenbacher, E. G., Rinko, C. J. \& Pi-Sunyer, F. X. (1985). The effects of inorganic chromium and brewer's yeast on glucose tolerance, plasma lipids and plasma chromium in elderly subjects. American Journal of Clinical Nutrition 42, 454-461.

Potter, J. F., Levin, P., Anderson, R. A., Freiberg, J. M., Andres, R. \& Elahi, D. (1985). Glucose metabolism in glucose intolerant older people during chromium supplementation. Metabolism 34, 199-204.

Preston, A. M., Dowdy, R. P., Preston, M. A. \& Freeman, J. N. (1976). Effect of dietary chromium on glucose tolerance and serum cholesterol in guinea pigs. Journal of Nutrition 106, 1391-1397.

Rabinowitz, M. B., Gonick, H. C., Levin, S. R. \& Davidson, M. B. (1983). Effects of chromium and yeast supplements on carbohydrate and lipid metabolism in diabetic men. Diabetes Care 6, 319-327.

Ranganathan, S., Jackson, R. L. \& Harmony, J. A. K. (1982). Effect of pantethine on the biosynthesis of cholesterol in human skin fibroblasts. Atherosclerosis 44, 261-273.

Riales, R.\& Albrink, M. J. (198I). Effect of chromium chloride supplementation on glucose tolerance and serum lipids including high-density lipoprotein of adult men. American Journal of Clinical Nutrition 34, $2670-2678$. 
Roitelman, J. \& Schecter, I. (1984). Regulation of rat liver 3-hydroxy-3-methylglutaryl coenzyme A reductase. Journal of Biological Chemistry 259, 870-877.

Roitelman, J. \& Schecter, I. (1986). Altered kinetic properties of rat liver 3-hydroxy-3-methylglutaryl coenzyme A reductase following dietary manipulations. Journal of Biological Chemistry 261, 5061-5066.

Schroeder, H. A. (1969). Serum cholesterol and glucose levels in rats fed refined and less refined sugars and chromium. Journal of Nutrition 97, 237-242.

Schwarz, K. (1951). Production of dietary necrotic liver degeneration using American Torula yeast. Proceedings of the Society for Experimental Biology and Medicine 77, 818-823.

Schwarz, K. \& Mertz, W. (1959). Chromium III and the glucose tolerance factor. Archives of Biochemistry and Biophysics 85, 292-295.

Simonoff, M., Llabador, Y., Hamon, C., Peers, A. M. \& Simonoff, G. N. (1984). Low plasma chromium in patients with coronary artery and heart disease. Biological Trace Element Research 6, 431-439.

Smith, I. (1969). Chromatographic and Electrophoretic Techniques. vol. 1, 3rd ed., p. 104. Bath: Pitman.

Stoecker, B. J. \& Oladut, W. K. (1985). Effects of chromium and ascorbate deficiencies on glucose tolerance and serum cholesterol of guinea pigs. Nutrition Reports International 32, 399405.

Uusitupa, M. I. J., Kumpulainen, J. T., Voutilainen, E., Hersio, K., Sarlund, H., Pyorala, K. P., Kiovistoinen, P. E. \& Lehto, J. T. (1983). Effect of inorganic chromium supplementation on glucose tolerance, insulin response, and serum lipids in non-insulin-dependent diabetes. American Journal of Clinical Nutrition 38, 404-410.

Vinson, J. A. \& Bose, P. (1984). The effect of a high-chromium yeast on the blood glucose control and blood lipids of normal and diabetic human subjects. Nutrition Reports International 30, 911-918.

Wallach, S. (1985). Clinical and biochemical aspects of chromium deficiency. Journal of the American College of Nutrition 4, 107-120 